\title{
Convulsions during cataract surgery under peribulbar anesthesia: a case report
}

\author{
Mustapha Bensghir*, Najlae Badou, Abdelhafid Houba, Hicham Balkhi, Charki Haimeur and Hicham Azendour
}

\begin{abstract}
Introduction: Locoregional anesthesia techniques are increasingly used for cataract surgery. From these techniques, peribulbar anesthesia has been very successful over the retrobulbar anesthesia seen its effectiveness and safety. However, peribulbar anesthesia is not without risk.

Case presentation: A 70-year-old African man was scheduled for cataract surgery and lens implant for his right eye. His medical history included hypertension, diabetes mellitus and gall bladder surgery. There were no personal or family antecedents of allergy, epilepsy or taking food or toxic drug. No abnormalities were detected in his preoperative evaluation. In the operating room, standard monitoring was installed and a peripheral venous catheter $18 \mathrm{~g}$ was inserted. Peribulbar anesthesia was realized with two injections in primary gaze position. The anesthetic mixture contained lidocaine $2 \%$ and bupivacaine $0.5 \%$. The needle used was $25 \mathrm{GA}, 19 \mathrm{~mm}, 3 / 4 \mathrm{inch}$. The first injection was performed in his lower temporal peribulbar space with $5 \mathrm{~mL}$ of mixture; the second injection was performed with $3 \mathrm{~mL}$ of mixture in his upper nasal peribulbar space. These injections were performed after a negative aspiration test and followed by manual compression of his globe for 5 minutes. Five minutes after peribulbar anesthesia, his blood pressure increased to $209 / 115 \mathrm{mmHg}$ requiring three bolus of nicardipine (3.0 mg) to reduce his blood pressure to $134 / 56 \mathrm{mmHg}$. One minute after, he had generalized tonic-clonic seizures. Tracheal intubation was performed. His capillary blood glucose was $170 \mathrm{mg} / \mathrm{dL}$, axillary temperature was $36.5^{\circ} \mathrm{C}$, and his serum electrolytes were normal. He recovered spontaneous ventilation 1.5 hours later. A neurological examination noted no deficit. Extubation was performed 15 minutes later without incident. A brain computed tomography and electroencephalogram were unremarkable. He was discharged on the second day and operated on 1 month later under general anesthesia.
\end{abstract}

Conclusions: Various serious complications can occur during locoregional anesthesia techniques in ophthalmic surgery. The mastering and perfecting of these techniques by practitioners and compliance with safety standards in anesthesia are the only way to guarantee the prevention of such complications.

Keywords: Brainstem anesthesia, Cataract surgery, Convulsions, Peribulbar anesthesia

\section{Introduction}

In ophthalmic surgery several anesthetic techniques are possible [1-3]. The use of locoregional anesthesia (LRA) is more practiced at the expense of general anesthesia. These techniques have had major developments in recent years [4-6].

From these techniques, peribulbar anesthesia (PBA) has been very successful over the retrobulbar anesthesia seen its effectiveness and safety [7,8]. Despite this success, varying complications during PBA have been

\footnotetext{
* Correspondence: mustaphabens_15rea@hotmail.com

Department of Anesthesiology Military Hospital Mohammed V Rabat, University of Mohammed V Souissi, Rabat, Morocco
}

described [9-11]. Of these, convulsions are a serious complication [12-14].

Through a clinical case of a convulsion during PBA and a literature review, we discuss the mechanisms involved in this complication and possible means of prevention.

\section{Case presentation}

A 70-year-old, 83kg African man was scheduled for cataract surgery and lens implant for his right eye. His medical history included hypertension, diabetes mellitus and gall bladder surgery under general anesthesia. There was no surgery on his contralateral eye. His medications included amlodipine, insulin, antiplatelets and statins. 
There were no personal or family antecedents of allergy, epilepsy or taking food or toxic drug.

A routine preoperative evaluation noted a blood pressure (BP) of $149 / 78 \mathrm{mmHg}$, a heart rate (HR) of 81 beats/minute and arterial oxygen saturation $\left(\mathrm{SpO}_{2}\right)$ of $99 \%$.

A clinical examination did not show dyspnea or angina. No abnormalities were detected on an electrocardiogram and a chest X-ray. In laboratory tests, his blood glucose was $158 \mathrm{mg} / \mathrm{dL}$, urea plasma was $0.49 \mathrm{~g} / \mathrm{L}$ and creatinine was $13 \mathrm{mg} / \mathrm{L}$. In the anesthetic consultation, it was decided to continue all treatments and to stop insulin on the morning of surgery. After a preoperative fasting of 6 hours, premedication by hydroxyzine $(75 \mathrm{mg})$, and oral administration of prophylactic antibiotic (ciprofloxacin $1 \mathrm{~g}$ ), the patient was admitted to the operating room where monitoring including $\mathrm{BP}, \mathrm{HR}$ and $\mathrm{SpO}_{2}$ was installed (Zeus Infinity Empowered Dräger Medical AG \& Co. KG. Lübeck, Germany). A peripheral venous catheter $18 \mathrm{~g}$ was inserted in his right hand and powered by an infusion of saline serum (0.9\%).

After swabbing and explanation of the technique to the patient, we proceeded to PBA with two injections in primary gaze position. The anesthetic mixture contained lidocaine $2 \%$ and bupivacaine $0.5 \%$. The needle used was 25GA, 19mm, 3/4 inch (Alcon ${ }^{\oplus}$ Surgical Malmaison Cedex, France). The first injection was performed in his lower temporal peribulbar space with $5 \mathrm{~mL}$ of mixture; the second injection was performed with $3 \mathrm{~mL}$ of mixture in his upper nasal peribulbar space. These injections were performed after a negative aspiration test and followed by manual compression of his globe for 5 minutes. During injections no change in $\mathrm{BP}, \mathrm{HR}$ or $\mathrm{SpO}_{2}$ was noted. Five minutes after PBA, his BP increased to $209 / 115 \mathrm{mmHg}$ but his HR did not change (85 beats/minute) neither did his $\mathrm{SpO}_{2}$ (99\%). This hypertension lasted 3 minutes; three bolus of nicardipine (3.0mg) were required to reduce his BP to 134/ $56 \mathrm{mmHg}$. One minute after, he had generalized tonicclonic seizures. He was placed in a lateral position and $3 \mathrm{mg}$ of midazolam was administered. Tracheal intubation was performed successfully after a bolus of propofol (150mg) and fentanyl $(150 \mu \mathrm{g})$ without muscle relaxants. The controlled ventilation was made with sedation by isoflurane $1 \%$. His capillary blood glucose was $170 \mathrm{mg} / \mathrm{dL}$, axillary temperature was $36.5^{\circ} \mathrm{C}$, and his serum electrolytes were normal. He recovered spontaneous ventilation 1.5 hours later. A neurological examination noted no deficit. Extubation was performed 15 minutes later without incident. A brain computed tomography and electroencephalogram were unremarkable. He was discharged on the second day and operated on 1 month later under general anesthesia.

\section{Discussion}

There has been much development in LRA in recent years from a technical standpoint and in equipment. In ophthalmic surgery, PBA has been very successful over the retrobulbar anesthesia seen its effectiveness and safety $[7,8]$. Despite this success, varying complications during PBA have been described. Of these, convulsions represent a serious complication [12-14].

During surgery under LRA, convulsions may have several causes such as hypoglycemia, medication errors, stroke, severe hypoxia caused by deep sedation or following a cardiac arrest complicating cardiac ocular reflex and central nervous system intoxication by spread of local anesthetic agent (LAA) (Table 1). Several mechanisms may explain the spread of LAA used in PBA to brain structures causing various neurological signs.

The first mechanism is an inadvertent intra-arterial injection in the ophthalmic artery or its branches. The injection pressure can reverse the direction of blood flow in the artery and the anesthetic solution flows back into the internal carotid artery and is delivered to the thalamus and other midbrain structures [14-16].

Indeed the ophthalmic artery is in an abnormal position inferior to the optic nerve in $15 \%$ of cases, this exposes inadvertent intra-arterial injection during a PBA [16]. In this case, the direct exposure of brain structures to a low volume of LAA is similar to intoxication after inadvertent peripheral intra-arterial injection of a large volume of LAA, thereby clinical presentation is similar. Clinical signs have rapid onset and can range from loss of consciousness to cardiac arrest. Convulsions may be present or replaced by an electric silence [17].

The second mechanism is inadvertent brainstem anesthesia [18-21]. The optic nerve is surrounded by three envelopes, which are an extension of the cerebral meninges. Studies have shown that there is communication between the central cerebral structures and the optic nerve [22,23]. Thereby an accidental injection through these envelopes causing a diffusion of LAA under arachnoid or subdural space to brain structures can cause a direct intoxication of brain structures. The main risk factors for this iatrogenic injection are the size of the needle used and the position of the eye at the time of realization of the PBA.

During PBA, with the globe in superonasal gaze, the optic nerve is in close proximity to the introduced needle [10]. In this superonasal gaze position, the risk of puncture of the envelope of the optic nerve is important with a diffusion of LAA into the brain structures. However, in a primary gaze position, the risk of accidental puncture of the optic nerve is low.

Although the distance between the temporal region and lower optical foramen is between $42 \mathrm{~mm}$ and $54 \mathrm{~mm}$, the use of shorter needles between $16 \mathrm{~mm}$ and $25 \mathrm{~mm}$ and a higher volume of LAA allows, after a period of time, complete anesthesia. The onset of action is explained by the diffusion of LAA at the site of action. With these needles the risk of puncture of the optic nerve is low in 
Table 1 Perioperative causes of convulsions and their management and prevention

\begin{tabular}{|c|c|c|c|}
\hline Causes & Symptoms & Management & Prevention \\
\hline \multirow[t]{2}{*}{ Oculocardiac reflex } & \multirow[t]{2}{*}{ Bradycardia/cardiac arrest } & Release of muscle tension & Gentle muscle tractions \\
\hline & & Injection of atropine & Injection of atropine \\
\hline \multirow[t]{2}{*}{ Drug errors } & \multirow{2}{*}{$\begin{array}{l}\text { Tachycardia/bradycardia/convulsions... } \\
\text { (depends on type of drugs injected) }\end{array}$} & \multirow[t]{2}{*}{ Symptomatic treatment } & Labeling of syringes \\
\hline & & & $\begin{array}{l}\text { Verification of syringes before } \\
\text { injection }\end{array}$ \\
\hline \multirow[t]{2}{*}{ Hypoglycemia } & \multirow[t]{2}{*}{$\begin{array}{l}\text { Sweating, drowsiness, confusion, abnormal } \\
\text { behavior ... convulsions }\end{array}$} & \multirow[t]{2}{*}{$\begin{array}{l}\text { Administration of serum } \\
\text { glucose }(10 \%)\end{array}$} & $\begin{array}{l}\text { No taking of hypoglycemic } \\
\text { medications the morning of surgery }\end{array}$ \\
\hline & & & $\begin{array}{l}\text { Perioperative monitoring of blood } \\
\text { glucose }\end{array}$ \\
\hline \multirow[t]{3}{*}{ Hypoxia } & \multirow{3}{*}{$\begin{array}{l}\text { Desaturation, consciousness disorders ... } \\
\text { convulsions. }\end{array}$} & \multirow{3}{*}{$\begin{array}{l}\text { Oxygen therapy, liberation of } \\
\text { superior airways, intubation }\end{array}$} & Monitoring of oxygen saturation \\
\hline & & & $\begin{array}{l}\text { Systematic supplemental oxygen } \\
\text { during sedation }\end{array}$ \\
\hline & & & Monitoring of sedation \\
\hline \multirow[t]{3}{*}{ Stroke } & \multirow{3}{*}{$\begin{array}{l}\text { Consciousness disorders, respiratory } \\
\text { distress, hemodynamic instability, convulsions }\end{array}$} & \multirow{3}{*}{$\begin{array}{l}\text { Control of airway, control of } \\
\text { hemodynamics parameters }\end{array}$} & Management of cardiovascular drugs \\
\hline & & & Neurological monitoring \\
\hline & & & $\begin{array}{l}\text { Maintaining a stable hemodynamic and } \\
\text { normal oxygenation }\end{array}$ \\
\hline \multirow[t]{4}{*}{ Toxicity of local anesthetics } & Somnolence, diplopia, shivering, & Oxygen therapy & Aspiration before injection \\
\hline & Difficulty speaking, arrhythmias & Airway liberation & Reduction of local anesthetic doses \\
\hline & \multirow[t]{2}{*}{ Convulsions, coma } & Anticonvulsants, & Use of ultrasound \\
\hline & & Fat emulsion & \\
\hline
\end{tabular}

comparison with the use of long needles of $31 \mathrm{~mm}$ or more, which provide an immediate anesthesia with a low volume of LAA, but increase the risk of puncture of the optic nerve [24,25]. Another mechanism that can be evoked is the absorption of LAA by the arachnoid villi and spread to cerebral structures [26]. This absorption is favored by manual compression and the use of hyaluronidase.

In our patient, there was no hypoglycemia (capillary blood glucose was $170 \mathrm{mg} / \mathrm{dL}$ ), no medication error in the verification of injected drugs, and no metabolic disorders in laboratory analysis. There was no neurological deficit after awakening and his postoperative brain computed tomography was normal eliminating a cerebral stroke. Thus, the convulsions were very probably related to PBA technique.

The delayed onset of convulsions after PBA and recovery of spontaneous ventilation after 1 hour are in favor of the second mechanism (inadvertent brainstem anesthesia). Using a $19 \mathrm{~mm}$ needle in our case, we cannot exclude the possibility of this mechanism. Two elements are against the first mechanism of intra-arterial injection: negativity of needle aspiration test and delayed onset of symptoms. Whatever the mechanism involved in this complication, prevention is necessary to avoid the occurrence of such complications.

During these last years, surgeons increasingly perform LRA in ophthalmic surgery [27]; this raises the question of the necessity of the presence of anesthetists in the operative room. This presence of anesthetists always remains required during the LRA for the management of complications.

The respect of standards in anesthetic safety in ophthalmic surgery is mandatory $[28,29]$. The type of monitoring used during ophthalmic local anesthesia should be similar to that used during general anesthesia and all technical and human resources must be available, in the operative room, to deal with the occurrence of any complications [30]. The other elements of prevention are: the systematic practice of needle test aspiration before each injection, maintaining the position of the globe in a neutral position at the completion of the PBA, and the use of needles no longer than $25 \mathrm{~mm}$.

The use of ultrasound in LRA in ophthalmic surgery could help guide the direction of the needle, see the injection sites, reduce the volume of injected LAA and reduce the complication rate and improve the safety and performance of these techniques. These benefits have already been demonstrated in LRA for other surgeries; in ophthalmic surgery, the use of ultrasound for the realization of LRA is in full development [31-33].

\section{Conclusions}

LRA techniques in ophthalmic surgery should not be trivialized. Various serious complications can occur during LRA techniques in ophthalmic surgery. 
The mastering and perfecting of these techniques by practitioners and compliance with safety standards in anesthesia are the only way to guarantee the prevention of such complications.

\section{Consent}

Written informed consent was obtained from the patient for publication of this case report and accompanying images. A copy of the written consent is available for review by the Editor-in-Chief of this journal.

\section{Abbreviations}

BP: Blood pressure; HR: Heart rate; LAA: Local anesthetic agent;

LRA: Locoregional anesthesia; PBA: Peribulbar anesthesia; $\mathrm{SpO}_{2}$ : Arterial oxygen saturation.

\section{Competing interests}

The authors declare that they have no competing interests.

\section{Authors' contributions}

$M B, N B$ and $A H$ analyzed and interpreted the patient data. $M B$ and $N B$ were major contributors in writing the manuscript. $\mathrm{HB}, \mathrm{CH}$ and $\mathrm{HA}$ made the final corrections. All authors read and approved the final manuscript.

Received: 25 November 2013 Accepted: 28 April 2014

Published: 23 June 2014

\section{References}

1. Haberer JP, Obstler C: Anesthésie en Ophtalmologie, EMC Anesthésie-Réanimation. Paris: Elsevier Masson SAS; 2008:1-24. 36-620-E-30.

2. McGoldrick KE, Foldes PJ: General anesthesia for ophthalmic surgery. Ophthalmol Clin North Am 2006, 19:179-191.

3. Ripart J, Nouvellon E, Chaumeron A: Regional anesthesia for eye surgery. Reg Anesth Pain Med 2005, 30:72-82.

4. Nouvellon E, Cuvillon P, Ripart J: Regional anesthesia and eye surgery. Anesthesiology 2010, 113:1236-1242.

5. Aqil M: Local anesthesia for the ophthalmic surgery. Select the best technique for your patient. Saudi Med J 2010, 31:605-614.

6. Kumar C, Dowd T: Ophthalmic regional anaesthesia. Curr Opin Anaesthesiol 2008, 21:632-637.

7. Weiss $J \mathrm{~L}$, Deichman CB: A comparison of retrobulbar and periocular anesthesia for cataract surgery. Arch Ophthalmol 1989, 107:96-98.

8. Alhassan MB, Kyari F, Ejere HO: Peribulbar versus retrobulbar anaesthesia for cataract surgery. Cochrane Database Syst Rev 2008, 16(3), CD004083. doi:10.1002/14651858.CD004083.pub2.

9. Davis DB, Mandel MR: Peribulbar anesthesia. A review of technique and complications. Ophthalmol Clin North Am 1990, 3:101-110.

10. Rouxel JM, Zahwa A, Obstler C, Haberer JP: Complications de l'anesthésie rétrobulbaire et péribulbaire. Cah Anesthesiol 1997, 45:193-205.

11. Davis DB 2nd, Mandel MR: Efficacy and complication rate of 16,224 consecutive peribulbar blocks. A prospective multicenter study. J Cataract Refract Surg 1994, 20:327-337.

12. Boret $H$, Petit $D$, Ledantec $P$, Bénéfice $S$ : Brainstem anesthesia after peribulbar anesthesia. Ann Fr Anesth Reanim 2002, 21:725-727.

13. Rozentsveig $V$, Yagev R, Wecksler N, Gurman G, Lifshitz T: Respiratory arrest and convulsions after peribulbar anesthesia. J Cataract Refract Surg 2001, 27:960-962

14. Gomez R, Andrade L, Rezende Costa JR: Brainstem anaesthesia after peribulbar anesthesia. Can J Anaesth 1997, 44:732-734.

15. Aldrete JA, Romo-Salas F, Arora S, Wilson R, Rutherford R: Reverse arterial blood flow as a pathway for central nervous system toxic responses following injection of local anesthetics. Anesth Analg 1978, 57:428-433.

16. Meyers EF, Ramirez RC, Boniuk I: Grand mal seizures after retrobulbar block. Arch Ophthalmol 1978, 96:847.

17. Rosenblatt RM, May DR, Barsoumian K: Cardiopulmonary arrest after retrobulbar block. Am J Ophthalmol 1980, 90:425-427.

18. Hamilton RC: Brain-stem anesthesia as a complication of regional anesthesia for ophthalmic surgery. Can J Ophthalmol 1992, 27:323-325.
19. Renato S, Gomez MSC, Andrade LOF, Rezende Costa JR: Brainstem anaesthesia after peribulbar anaesthesia. Can J Anaesth 1997, 44:732-734.

20. Edge KR, Davis A: Brainstem anaesthesia following a peribulbar block for eye surgery. Anaesth Intensive Care 1995, 23:219-221.

21. Singer SB, Preston RG, Hodge W: Respiratory arrest following anesthesia for cataract surgery: case report and review of the literature. Can J Ophthalmol 1997, 32:450-454.

22. Kobet KA: Cerebral spinal fluid recovery of lidocaine and bupivacaine following respiratory arrest subsequent to retrobulbar block. Ophtalmic Surg 1987, 1:11-13.

23. Red JW, Mac Millan AS, Lazenby GW: Transient neurologic complication of positive contrast orbitography. Arch Ophtalmol 1969, 81:508-511.

24. Katsev DA, Drews RC, Rose BT: An anatomic study of retrobulbar needle path length. Ophthalmology 1989, 96:1221-1224.

25. Ortiz M, Valls R, Vallès J, Blanco D, Vidal F: Topography of peribulbar anesthesia. Reg Anesth 1995, 20:337-342.

26. Shantha TR: The relationship of retrobulbar local anaesthetic spread to the neural membranes of the eyeball, optic nerve, and arachnoid villi in the optic nerve. Anesthesiology 1990, 72(3A):A849.

27. Chandradeva K, Nangalia V, Hugkulstone CE: Role of the anaesthetist during cataract surgery under local anaesthesia in the UK: a national survey. Br J Anaesth 2010, 104:577-581.

28. Merry AF, Cooper JB, Soyannwo O, Wilson IH, Eichhorn JH: International standards for a safe practice of anesthesia 2010. Can J Anaesth 2010, 57:1027-1034

29. Mellin-Olsen J, Staender S, Whitaker DK, Smith AF: The Helsinki declaration on patient safety in anaesthesiology. Eur J Anaesthesiol 2010, 27:592-597.

30. Kumar CM, Eke T, Dodds C, Deane JS, El-Hindy N, Johnston RL, Kong KL, McLure HA, Shah P, Tighe SQ, Vohra SB: Local anaesthesia for ophthalmic surgery - new guidelines from the Royal College of Anaesthetists and the Royal College of Ophthalmologists. Eye (Lond) 2012, 26:897-898.

31. Luyet C, Eichenberger U, Moriggl B, Remonda L, Greif R: Real-time visualization of ultrasound-guided retrobulbar blockade: an imaging study. Br J Anaesth 2008, 101:855-859.

32. Chang WM, Stetten GD, Lobes LA Jr, Shelton DM, Tamburo RJ: Guidance of retrobulbar injection with real-time tomographic reflection. J Ultrasound Med 2002, 21:1131-1135.

33. Luyet C, Eng KT, Kertes PJ, Avila A, Muni RH, McHardy P: Real-time evaluation of diffusion of the local anesthetic solution during peribulbar block using ultrasound imaging and clinical correlates of diffusion. Reg Anesth Pain Med 2012, 37:455-459.

\section{doi:10.1186/1752-1947-8-218}

Cite this article as: Bensghir et al: Convulsions during cataract surgery under peribulbar anesthesia: a case report. Journal of Medical Case Reports 2014 8:218.

\section{Submit your next manuscript to BioMed Central and take full advantage of:}

- Convenient online submission

- Thorough peer review

- No space constraints or color figure charges

- Immediate publication on acceptance

- Inclusion in PubMed, CAS, Scopus and Google Scholar

- Research which is freely available for redistribution 